\title{
MENINJAU KINERJA BANK SYARIAH DI INDONESIA
}

\author{
Fitri Sagantha \\ Universitas Pamulang, Banten \\ dosen02329@unpam.ac.id
}
Submitted: $22^{\text {nd }}$ August 2019/ Edited: $15^{\text {th }}$ November 2019/ Issued: $01^{\text {st }}$ January 2020
Cited on: Sagantha, Fitri. (2020). MENINJAU KINERJA BANK SYARIAH DI
INDONESIA. SCIENTIFIC JOURNAL OF REFLECTION: Economic, Accounting, Management and Business, 3(1), 41-50.
DOI:
https://doi.org/

\begin{abstract}
To show the role, then show the performance. Maybe, the term is right for the bank. The existence of banks influences economic stability, therefore financial performance must be good. There is no choice but to increase the entire financial ratio. Interest in reviewing the financial ratios of banks, especially Islamic banks, is the goal to be achieved in this study. Use financial statements as data, and analyze the extent of their performance and influence. For this reason, a quantitative approach and regression analysis are needed. So that research results can be explained properly. The findings in this study suggest that the performance of Islamic banks is relative. Its role is not yet at a significant stage for the economy, and it is still far from conventional banks.
\end{abstract}

Keywords: ROA, ROE, CAR, NPF, FDR, BOPO

\section{PENDAHULUAN}

Menggeliatnya bank syariah merupakan tanda semarak pembaharuan. Hampir di semua sektor melabelkan produknya dengan syariah, tidak terkecuali perbankan. Sejak undang-undang perbankan syariah ditandatangani pada 1992 semarak perbankan syariah di Indonesia semakin pesat, terlebih ketika terjadi krisis keuangan dunia tahun 2008, dan di saat yang sama disahkannya undang-undang baru tentang perbankan syariah, yang mengatur secara fundamental bagaimana perbankan syariah beroperasi, banyak bank-bank syariah bermunculan. OJK (2019) mencatat sebanyak 202 lembaga keuangan syariah terdiri dari bank umum syariah sebanyak 14 bank, bank perkreditan rakyat syariah sebanyak 168 BPRS, dan unit usaha syariah sebanyak 20 usaha.

Kemajuan di atas cukup menggembirakan dari sisi kuantitas, namun hal yang masih dipertanyakan bagaimana perannya bagi kemajuan ekonomi di Indonesia. Data OJK (2019) menunjukkan bahwa perolehan laba bank umum syariah pada tahun 2016 
sebesar 3.442 milyar, pada tahun 2017 sebesar 4.032 milyar, pada tahun 2018 sebesar 5.757 milyar, dan per bulan September 2019 perolehan laba bank umum syariah sebesar 7.833 milyar. Data ini menjelaskan bahwa bank umum syariah cukup menjanjikan karena tren laba yang didapat meningkat, meskipun dari sisi jumlah belum memiliki arti apa-apa bagi skala makro.

Selain itu, dari sisi laba rugi OJK (2019) mencatat sebesar 952 juta pada tahun 2016, sedangkan pada tahun 2017 sebesar 990 juta, pada tahun 2018 sebesar 2.806 milyar dan pada tahun 2019 sebesar 2.962 milyar. Sisi aset produktif per bulan Desember tahun 2016 sebesar 3.50\%, tahun 2017 sebesar 3.57\%, dan tahun 2018. Data tersebut menunjukkan angka fluktuasi.

OJK (2019) juga melaporkan kontribusi bank umum syariah dari sisi pembiayaan atau dalam istilah bank konvensional dikenal dengan pemberian kredit, di mana total pembiayaan pada tahun 2016 mencapai 177.482 milyar dengan tingkat NPF sebesar 7.834, sedangkan pada tahun 2017 total pembiayaan sebesar 189.789 milyar dan NPF sebesar 9.030, dan total pembiayaan pada tahun 2018 sebesar 202.298 dan tingkat NPF sebesar 6.597.

Dari banyaknya pembiayaan yang diberikan, porsi atau pengguna pembiayaan didominasi oleh sektor UMKM dengan total pembiayaan sebesar 248 milya pada tahun 2016, pada tahun 2017 sebesar 286 milyar, pada tahun 2018 sebesar 320 milyar, dan pada bulan September tahun 2019 sebesar 344 milyar. Tren penyaluran pembiayaan cukup baik, dari tahun ke tahun terus meningkat. Kendati demikian besarnya masih jauh dari kata membangun, namun setidaknya secara perlahan peran perbankan syariah terus berkontribusi.

Dalam banyak riset, era syariah telah menarik minat ekonom dunia, bahkan banyak negara-negara maju di Eropa dan Amerika sebagian unit usahanya telah beralih ke model syariah. Mengingat kekuatan pada sistem syariah ada pada konsep fundamental, yakni mengedepankan hak dan keuntungan konsumen ketimbang keuntungan perusahaan. Tentu di era digital dan modern, konsumen telah berkembang menjadi lebih cerdas dalam bersikap, khususnya pada saat berekonomi. Mereka akan mencari hal yang lebih menguntungkan baginya, melihat sisi mana yang pas bagi keadaan ekonomi dan kesejahteraan. Tentu ini akan menjadi hal-hal yang sulit bagi 
usaha syariah, karena harus berjuang keras untuk memperkenalkan dan mendapatkan pangsa pasar konvensional/ kapital.

Febrianti \& Ashar (2016), peran bank syariah baru pada tahap permulaan, di mana preferensi dan persepsi baru dibangun, dan tentu ke depan bank syariah dan atau unit Syariah akan mendominasi. Hal tersebut, adanya perbedaan yang besar dari sisi konsep yang ditawarkan, di mana syariah lebih pro konsumen atau nasabah dalam pemberian kreditnya, terlebih dalam hal deposito, syariah jauh lebih unggul. Kemudian, konsistensinya di dalam menjaga kepercayaan bank syariah lebih kuat. Namun kelemahan terbesarnya adalah fundamental keuangan syariah belum stabil, sehingga sistem masih lemah terhadap berbagai risiko, khususnya dari pasar.

Di si lain, Rama (2013) menegaskan, dalam konteks perekonomian perbankan syariah belum menunjukkan titik terang sebagaimana seka terjang bank konvensional, namun dengan tren kesadaran masyarakat muslim seiring waktu akan membuahkan hasil di masa mendatang. Akan tetapi pekerjaan rumahnya adalah bagaimana bank syariah mampu membangun sistem keuangan yang kokoh secara fundamental, sehingga cukup kuat menghadapi serangan keuangan dunia.

Syukron, A. (2013) dan Sari, dkk (2013) perkembangan bank syariah belum tinggi, namun dari sisi BPRS dan uni usaha syariah cukup pesat. Artinya, masih banyak perusahaan-perusahaan yang menunggu sampai pada titik di mana lembaga keuangan syariah menjadi pilihan masyarakat, sehingga kontribusinya di dalam memajukan perekonomian lebih signifikan seiring tren minat masyarakat. Karena kenyataanya, Vivin \& Wahono (2017), Aisjah \& Hadianto (2015), dan Rama (2015) mengemukakan, dominasi bank konvensional masih besar, secara persentase bank umum jauh lebih punya peran, terlebih di pelosok desa, masyarakat masih bergantung dengan sistem konvensional.

Tidak dapat dipungkiri bahwa bank syariah adalah suatu konsep baru yang memiliki harapan baru untuk menata suatu perekonomian yang lebih berkeadilan. Bahwa apa yang telah dipersepsikan saat ini dari sisi konvensional bukan berarti syariah tidak punya pangsa pasar atau kontribusi, namun seiring berjalannya waktu kesadaran masyarakat akan meningkat dan melihat soal wacana ekonomi yang lebih baik, yakni pengelolaan usaha yang memberikan keadilan bagi seluruh pihak-pihak yang terlibat, dengan tidak mengambil satu keuntungan dari orang lain. Bukti ini yang yang terus 
ditingkatkan oleh perbankan syariah di Indonesia, dengan terus meningkatkan tata kelola, pelayanan, dan kinerja keuangan.

Berbagai rasio keuangan terus dijaga dari berbagai risiko mikro dan makro, serta terus ditingkatkan jumlah nasabah. OJK (2019) mencatat sebanyak 15.4 juta nasabah bank syariah pada tahun 2016, kemudian meningkat 2 juta rekening di tahun 2017 dengan total nasabah sebanyak 17.9 juta, sedangkan pada tahun 2018 jumlah nasabah bertambah menjadi 19.9 juta, dan di bulan September 2019 total jumlah nasabah yang buka rekening di bank syariah sebanyak 21.7 juta.

\section{LANDASAN TEORI}

Dari banyaknya indikator kinerja bank, yang paling mencolok adalah Retur On Asset (ROA). ROA merupakan rasio pendapatan yang utama dari rasio-rasio lain, mengingat perannya adalah sebagai laba bersih (Wibowo, 2016). Artinya, sejauh mana perusahaan itu memiliki potensi menghasilkan keuntungan dari bisnis yang dijalankannya. Jika suatu bank memiliki tingkat ROA yang baik (melebihi standar BI 3\%) maka dipersepsikan bank tersebut adalah perusahaan yang sehat, perusahaan yang layak diinvestasi, perusahaan yang dapat memberikan keuntungan, dll. Fadila (2015), mengemukakan tidak elok suatu bank yang fungsi utamanya mengelola uang namun ia sendiri kekurangan uang (keuntungan, modal, dll), maka patut dipertanyakan pengelolaannya. Darmawan \& Sukartha (2014) dan Prasetyaningrum (2014) sependapat, ROA merupakan ciri bahwa perusahaan dikelola dengan benar/ GCG, di mana tata kelola perusahaan telah memenuhi standar-standar yang baik.

Bank dikatakan baik juga karena memiliki tingkat Return On Equity/ ROE yang baik. Mengingat ROE juga disebut sebagai aset bersih, yang artinya ROE adalah ukuran di mana perusahaan mampu mengelola dana investasi atau modal. Dengan demikian, dana yang telah terhimpun dari masyarakat dapat menghasilkan suatu pendapatan (margin), yang juga dengan pendapatan tersebut dapat didistribusikan kepada pihakpihak terkait, termasuk masyarakat. Riana \& Dewi (2015) dan Nengsih (2015) mengemukakan, lembaga bank wajib memiliki kemampuan mengelola dana yang terhimpun, jika tidak maka berpotensi disalahgunakannya anggaran tersebut. Aditya \& Badjra (2018), bagi bank mampu mengoperasionalkan modal adalah fundamental, 
karena itu adalah dasar bagai bank menyalurkan pembiayaan, dan dari situ pula bank mendapatkan margin/ keuntungan (Suhardjanto, dkk., 2012; Nengsih, 2015).

Beberapa rasio yang mendukung kedua rasio (ROA dan ROE) di atas di antaranya Capital Adqecy Ratio (CAR), Non Performing Finance (NPF), Finance Debt to Ratio (FDR), dan Biaya Operasional terhadap Pendapatan Operasional (BOPO). CAR sederhananya dikatakan sebagai rasio modal. Maksudnya rasio cukup dana untuk membiayai berbagai kebutuhan keuangan masyarakat seperti pembiayaan usaha, kendaraan, rumah, pendidikan, konsumsi, dll. Abusharba, dkk (2013), dan Akhtar \& Sadaqat (2011), modal bagi bank adalah dasar dari operasionalisasi perusahaan, dengan demikian ia bisa eksis. Ariss \& Sarieddine (2007), syarat utama bank harus memiliki modal minimal yang cukup, jika tidak ia bisa saja tidak profesional dan kemudian rugi, jika itu dana orang lain maka tidak ada jaminan untuk mengembalikan uang tersebut.

Ketika bank modalnya cukup, selanjutnya menyalurkan kepada masyarakat berupa pembiayaan (FDR). Rupa pembiayaan sangat banyak bisa konsumsi, bisnis, maupun penggunaan lain. Namun bank harus hati-hati, artinya bank memiliki pengetahuan di dalam mengendalikan risiko kredit bermasalah (NPF), dengan demikian dana atau modal tetap terjaga, namun keuntungan meningkat. Jangan sampai pembiayaan (FDR) yang didanai dari modal pihak ketiga hilang tanpa ada kepastian pengembaliannya, karena bisa memicu resesi keuangan. Oleh karena itu, bank harus benar-benar pandai mengelola dana dengan memastikan mekanisme pembiayaan aman bagi semua pihak, sehingga tercipta ROA dan ROE yang maksimal (Setiawan \& Putri, 2013; Havidz \& Setiawan, 2015). Poetry \& Sanrego (2014), mengemukakan FDR adalah sumber pendapatan dan tugas utama bagi bank, namun NPF adalah faktor kebalikannya. Hal yang perlu dilakukan adalah mengendalikannya, bukan membatasi pembiayaan yang tidak berdasar.

BOPO adalah rasio pengendalian beban operasional. Artinya, bank harus mampu mengelola dengan baik seluruh aktivitas agar tidak membebani laba yang telah diperoleh. Dengan demikian laba operasional dapat membantun meningkatkan ROA/ ROE perusahaan. Sudarsono\& Saputri (2018) menjelaskan, OER atau BOPO adalah rasio pendukung di dalam membantu manajemen risiko dan laba perusahaan, dengan terkendalinya dua hal tersebut dapat mengoptimalkan kinerja keuangan perusahaan dan berdampak pada meningkatnya nilai perusahaan/saham (Shidiqi \& Rachmawati, 2018). 


\section{METODE PENELITIAN}

Data yang digunakan adalah data laporan OJK bulan September 2019. Laporan OJK menjadi rujukan utama di dalam melihat dan menganalisis perkembangan perbankan syariah secara umum, khususnya yang berkaitan dengan kinerja keuangan, dalam hal ini melihat 6 rasio keuangan, terdiri dari rasio modal (CAR), rasio pendapatan (ROA), rasio pengembalian (ROE), rasio penyaluran pembiayaan (FDR) dan tingkat kelancaran pembiayaan (NPF), serta rasio operasional (BOPO).

Data di analisis menggunakan pendekatan kuantitatif dengan cara deskriptif. Di mana analisis melihat dari sudut pandang tren atau tingkat perkembangan. Apakah dari ke 6 rasio tersebut menunjukkan suatu kinerja yang baik, sehingga dapat memberikan informasi tambahan tentang ekspektasi atau masa depan perbankan syariah di Indonesia. Dengan demikian masyarakat Indonesia yang notabene adalah muslim akan dapat mengambil sikap terhadap perbankan syariah.

\section{HASIL PENELITIAN}

Tabel 1. Rasio Keuangan Bank Syariah di Indonesia (Dalam Persen)

\begin{tabular}{|c|c|c|c|c|c|c|c|}
\hline $\mathrm{NO}$ & TAHUN & ROA & ROE & CAR & NPF & FDR & BOPO \\
\hline 1 & 2005 & 1.35 & 27.58 & 12.41 & 2.82 & 97.75 & 78.91 \\
\hline 2 & 2006 & 1.55 & 28.45 & 13.73 & 4.75 & 98.9 & 76.77 \\
\hline 3 & 2007 & 2.07 & 40.38 & 10.67 & 4.05 & 99.76 & 76.54 \\
\hline 4 & 2008 & 2.76 & 14.77 & 30.28 & 8.38 & 128.78 & 80.85 \\
\hline 5 & 2009 & 5.00 & 21.55 & 29.98 & 7.03 & 126.89 & 64.69 \\
\hline 6 & 2010 & 3.49 & 14.29 & 27.46 & 6.50 & 128.47 & 78.08 \\
\hline 7 & 2011 & 2.67 & 18.95 & 23.49 & 6.11 & 127.71 & 76.31 \\
\hline 8 & 2012 & 2.64 & 20.54 & 25.16 & 6.15 & 120.96 & 80.02 \\
\hline 9 & 2013 & 2.79 & 21.22 & 22.08 & 6.50 & 120.93 & 80.75 \\
\hline 10 & 2014 & 2.26 & 16.13 & 22.77 & 7.89 & 124.24 & 87.79 \\
\hline 11 & 2015 & 2.20 & 14.66 & 21.47 & 8.20 & 120.06 & 88.09 \\
\hline 12 & 2016 & 2.27 & 16.18 & 21.73 & 8.63 & 114.40 & 87.09 \\
\hline 13 & 2017 & 2.55 & 19.40 & 20.81 & 9.68 & 111.12 & 85.34 \\
\hline 14 & 2018 & 1.87 & 12.86 & 19.33 & 9.30 & 111.67 & 87.66 \\
\hline 15 & 2019 & 2.52 & 19.38 & 19.48 & 8.27 & 116.71 & 85.89 \\
\hline \multicolumn{2}{|c|}{ RATA-RATA } & 2.53 & 20.42 & 21.39 & 6.95 & 116.56 & 80.99 \\
\hline
\end{tabular}

Sumber: OJK (Statistik Perbankan Syariah), 2019

Pertumbuhan ROA pada bank syariah di Indonesia selama kurun waktu 2005 2019 masuk pada peringkat 1 (satu) dengan rata rata 2,53\%, di mana ROA > 1,5\%. 
Artinya pertumbuhan bank syariah di Indonesia sangat baik dari sisi laba. Kemampuannya dalam menghasilkan laba sangat baik.

Selain itu, pertumbuhan ROE rata sebesar $20.42 \%$ dengan tren fluktuasi. Pertumbuhan ROE tertinggi pada tahun 2007 sebesar 40.38, sedangkan pertumbuhan terendah ROE pada tahun 2018 sebesar 12.86\%. Data ini menegaskan, kemampuan bank syariah di Indonesia cukup baik dalam mengelola modal sehingga berpotensi menghasil laba yang lebih baik.

Rasio kecukupan modal atau CAR rata-rata sebesar $21.39 \%$, lebih besar dari $12 \%$ $(\mathrm{KPMM} \geq 12 \%)$. Artinya, modal minimal telah dipenuhi oleh bank-bank syariah di Indonesia, sehingga sangat aman di dalam menjalankan usahanya, terutama dalam menyalurkan pembiayaan. Dengan modal yang cukup maka dimungkinkan penyaluran pembiayaan dapat lebih optimal sehingga dimungkinkan peroleh margin/laba menjadi lebih besar.

Tingkat pembiayaan yang bermasalah masuk pada kategori 3 (cukup tinggi) dengan rata-rata NPF sebesar 6.95\% (Peringkat 3: 5\% $\leq$ NPF $<8 \%$ ). Data ini menjelaskan bahwa permasalahan pembiayaan di sektor perbankan syariah Indonesia harus diwaspadai. Ini menandakan perlu adanya perbaikan terhadap manajemen risiko sehingga permasalahan pembiayaan dapat diatasi lebih baik, dan risiko kerugian dapat dihindari seminimal mungkin. Tingkat pembiayaan sebesar $116.56 \%$ berada pada kategori aman di mana maksimum FDR adalah 120\%. Begitu pula dengan BOPO masih berada pada tahap wajar $(80.99 \%)$.

Pada model pertama, diketahui pengaruh CAR dan FDR tidak berpengaruh signifikan terhadap ROA. Sedangkan NPF dan BOPO berpengaruh signifikan terhadap ROA. Temuan ini menegaskan bahwa:

1. Bank syariah di Indonesia belum dapat memanfaatkan modal yang ada

2. Pembiayaan belum dapat disalurkan secara optimal

3. Sedangkan NPF cukup terjaga dengan baik sehingga mampu berkontribusi terhadap pendapatan.

4. Penekanan beban operasional yang dilakukan bank syariah di Indonesia sangat baik, sehingga mampu meningkatkan Perolehan laba. 
Pada persamaan ke dua diketahui bahwa NPF dan FDR tidak berpengaruh signifikan terhadap ROE, namun CAR dan BOPO berpengaruh signifikan. Temuan ini menjelaskan:

1. Rasio NPF tidak berpengaruh terhadap aset bersih. Hal ini menjelaskan jika bank syariah di Indonesia masih terus memperbaiki manajemen risiko sehingga manapun menekan pembiayaan yang bermasalah.

2. Lemahnya rasio FDR menjelaskan jika bank syariah di Indonesia belum memiliki pangsa pasar yang luas, sehingga jumlah pembiayaan belum bisa diandalkan dalam meningkatkan aset bersih.

3. Sedangkan modal yang ada cukup berarti di dalam meningkatkan laba investasi, sehingga dapat memenuhi segala likuiditas yang jatuh tempo.

4. Fakta statistik menunjukkan rasio BOPO pada bank syariah terjaga dengan baik. Artinya bank syariah di Indonesia mampu menekan beban-beban operasional sehingga pendapatan aset meningkat.

\section{KESIMPULAN}

Secara umum kinerja keuangan bank syariah di Indonesia masuk pada kategori cukup baik. Namun, secara bisnis belum dapat diandalkan masih banyak yang perlu ditingkatkan, baik dari sisi aset, modal, penekanan pembiayaan bermasalah, dan mereduksi beban-beban operasional. Dengan demikian potensi usaha dapat dioptimalkan dan berdampak pada peningkatan pendapatan (ROA dan ROE).

Selain itu, untuk dapat mengoptimalkan ROA bank syariah Indonesia harus memanfaatkan kemampuannya di dalam mengendalikan pembiayaan bermasalah/NPF dan pengendalian beban operasional. Dengan memperhitungkan aspek modal dan pembiayaan. Sehingga di masa-masa mendatang bank syariah di Indonesia cukup menjanjikan bagi kemajuan perekonomian Indonesia.

Sedangkan untuk meningkatkan ROE, bank syariah Indonesia harus menjadikan CAR dan BOPO sebagai prioritas peningkatan aset bersih, sehingga dapat mereduksi kekurangan pada rasio NPF dan FDR. Akan tetapi, hal yang perlu diingat adalah, pembiayaan harus dapat ditingkatkan sehingga modal yang ada tidak menjadi beban bagi BOPO, begitu pula NPF, harus benar-benar ditekan seminimal mungkin agar Perolehan laba menjadi lebih baik. 


\section{DAFTAR PUSTAKA}

. (2015). Analisis sistem tata kelola syariah bagi perbankan syariah di Indonesia dan Malaysia. Jurnal Bimas Islam, 8(1), 87-120.

Abusharba, M. T., Triyuwono, I., Ismail, M., \& Rahman, A. F. (2013). Determinants of capital adequacy ratio (CAR) in Indonesian Islamic commercial banks. Global review of accounting and finance, 4(1), 159-170.

Aditya, I. G. N. W., \& Badjra, I. B. (2018). Peran Profitabilitas Dalam Memediasi Pengaruh Tingkat Suku Bunga Dan Leverage Terhadap Return Saham. E-Jurnal Manajemen, 7(4), 1831-1861.

Aisjah, S., \& Hadianto, A. E. (2015). Performance Based Islamic Performance Index (Study on the Bank Muamalat Indonesia and Bank Syariah Mandiri). Asia-Pacific Management and Business Application, 2(2), 98-110.

Akhtar, M. F., Ali, K., \& Sadaqat, S. (2011). Factors influencing the profitability of Islamic banks of Pakistan. International Research Journal of Finance and Economics, 66(66), 1-8.

Ariss, R. T., \& Sarieddine, Y. (2007). Challenges in implementing capital adequacy guidelines to Islamic banks. Journal of banking regulation, 9(1), 46-59.

Darmawan, I. G. H., \& Sukartha, I. M. (2014). Pengaruh Penerapan Corporate Governance, Leverage, Roa, dan Ukuran Perusahaan pada Penghindaran Pajak. EJurnal Akuntansi, 143-161.

Fadila, D. (2015). PERAN ROA SEBAGAI PEMEDIASI CAR, NPL DAN LDR BANK PEMBANGUNAN DAERAH DI INDONESIA. Jurnal Manajemen dan Bisnis Sriwijaya, 13(2), 217-228.

Febrianti, S. E., \& Ashar, K. (2016). Analisis Pengaruh Pertumbuhan GDP, Inflasi, BI Rate dan Nilai Tukar Terhadap Kredit Bermasalah Pada Bank Konvensional dan Bank Syariah. Jurnal Ilmiah Mahasiswa FEB, 3(2).

Havidz, S. A. H., \& Setiawan, C. (2015). Bank efficiency and non-performing financing (NPF) in the Indonesian Islamic banks. Asian Journal of Economic Modelling, 3(3), 61-79.

Nengsih, N. (2015). Peran perbankan syariah dalam mengimplementasikan keuangan inklusif di indonesia. Jurnal Etikonomi, 14(2).

Poetry, Z. D., \& Sanrego, Y. D. (2014). Pengaruh variabel makro dan mikro terhadap NPL perbankan konvensional dan NPF perbankan syariah. Tazkia Islamic Finance and Business Review, 6(2).

Prasetyaningrum, M. (2014). Profitabilitas dan return saham: peran moderasi arus kas operasi dan ukuran perusahaan. Jurnal ekonomi dan bisnis, 17(1), 111-134.

Rama, A. (2013). Perbankan syariah dan pertumbuhan ekonomi Indonesia. Signifikan: Jurnal Ilmu Ekonomi, 2(1). 
Riana, I. K. T., \& Dewi, S. K. S. (2015). Peran EPS Dalam Memediasi Pengaruh ROE Terhadap Harga Saham Perusahaan Perbankan Di BEI. E-Jurnal Manajemen, $4(12)$.

Sari, M. D., Bahari, Z., \& Hamat, Z. (2013). Perkembangan Perbankan Syariah di Indonesia: Suatu Tinjauan. Jurnal Aplikasi Bisnis, 3(2), 120-138.

Setiawan, C., \& Putri, M. E. (2013). Non-performing financing and bank efficiency of Islamic banks in Indonesia. Journal of islamic finance and Business research, 2(1), 58-76.

Shidiqi, K. A., \& Rachmawati, A. (2018). Determinants of Sharia Banks' Efficiency In Indonesia: Panel Data Analysis. Jurnal Ekonomi Pembangunan: Kajian Masalah Ekonomi dan Pembangunan, 19(2), 186-195.

Sudarsono, H., \& Saputri, M. A. (2018). The Effect of Financial Performance toward Profit-Sharing Rate on Mudharabah Deposit of Sharia Banking in Indonesia. Muqtasid: Jurnal Ekonomi dan Perbankan Syariah, 9(1), 82-92.

Suhardjanto, D., Dewi, A., Rahmawati, E., \& Firazonia, M. (2012). Peran corporate governance dalam praktik risk disclosure pada perbankan Indonesia. Jurnal Akuntansi dan Auditing, 9(1), 16-30.

Syukron, A. (2013). Dinamika perkembangan perbankan syariah di Indonesia. Economic: Journal of Economic and Islamic Law, 3(2), 28-53.

Vivin, Y. A., \& Wahono, B. (2017). Analisis Perbandingan Kinerja Keuangan Bank Umum Syariah dengan Bank Umum Konvensional di Indonesia. Jurnal Ilmiah Riset Manajemen, 6(08).

Wibowo, A. (2016). Peran Kinerja Perusahaan Dan Risiko Sistematis Dalam Menentukan Pengaruh Inflasi Terhadap Nilai Perusahaan. Media Ekonomi dan Manajemen, 26(2). 